\section{THE REGENERATION OF THE BRITISH SCIENTIFIC INSTRUMENT TRADE AFTER THE WAR.}

M UCH attention is being paid at present to $\mathrm{M}$ the capture of Germany's foreign trade after the war, and the same arguments that apply in other spheres hold good for the scientific instrument trade as well. The Germans, thanks to their efficient organisation and methods of education, had been able, at the time the war broke out, to attain a supreme position in this branch of their export trade. To quote one instance from statistics: Germany exported to Russia alone, in 1913, mathematical, physical, and chemical instruments to the value of nearly two millions sterling, and chemical and pharmaceutical products to almost the same amount. While corresponding figures are not available in a complete form for similar British products, there is every reason to believe that they represent only a small fraction of these amounts.

The following notes, based on conversations the writer had with the directors of two of the leading German manufacturers of physical and chemical apparatus, will explain the reason for Germany's success and point out the direction in which British manufacturers should proceed after the war.

In nearly every case the German youth desiring to adopt scientific instrument making as a trade has to serve a long apprenticeship in the particular branch to which he intends to devote his energies. This training is supplemented by courses in elementary science (including in many cases mathematics) held in the continuation schools (Gewerbeschulen), of which there are one or more in any town of importance. Thus, in addition to knowing how to construct an instrument, the German craftsman generally knows exactly what function that instrument is intended to perform-he crystallises his scientific notions into his daily work. He also realises the value of precision. It is highly important, therefore, that English instrument makers should be afforded more ample facilities for obtaining this scientific training at the same time as their workshop experience, in order to avoid the mere mechanical repetition which their practical experience calls for.

In Germany there is closer rapprochement between instrument-making firms and college and university teachers, with the result that new forms of apparatus are being continually evolved for proving a given law or explaining a scientific phenomenon. A perusal of the catalogues of Kohl, Enencke, and other firms will show the diversity of apparatus that were current articles with these houses.

It is to be hoped that after the war some publishing house will consider the advisability of establishing a periodical devoted to the theoretical and practical side of instrument making. Germany possesses more than one such organ, viz. the Zeitschrift für Instrumentenkunde (with its supplement, Deutsche Mechaniker-Zeitung, de- voted to the practical side of instrument making) and Der Mechaniker. The former journal is at the same time one of the many organs of the Physikalisch-Technische Reichsanstalt (the German National Physical Laboratory). Whenever a purely physical instrument is designed in that institution, the experimental data leading up to its design, as well as the mechanical details, are published in the Zeitschrift für Instrumentenkunde, the editorial staff of which includes one or more members of the Reichsanstalt staff. The value of such a journal to instrument makers, especially when their own staff includes men with a thorough scientific training, is incalculable.

Again, in order to make scientific products known abroad, the Germans resorted to an extensive system of propaganda, by means of elaborate descriptive catalogues printed in the language of the country with which they wished to deal. Many of these catalogues embrace almost every known instrument for teaching and other purposes.

British manufacturers, my German informants told me, are quite as capable as the Germans of constructing instruments of precision equal in every respect to the German products. There is no reason, therefore, why they should not secure a large share of the business that was done by Germany in pre-war days, provided they (I) take steps to construct a more comprehensive range of apparatus; (2) keep pace with modern scientific requirements; (3) keep in closer touch with British men of science; (4) give more attention to the publication of catalogues in foreign languages; and (5) establish a journal embodying the peculiar features of the Zeitschrift für Instrumentenkunde.

E. S. HODGSON.

\section{DR. FELIX LE DANTEC.}

$I^{T}$ is with regret that we have to record the 1 death of a well-known French biologist, Dr. Félix Le Dantec, at the age of forty-eight years. For many years a sufferer, he hastened his end by generous work in the war hospitals, though indeed the flame of his life always burned too quickly to last long.

Of Breton extraction and precocious talents, Dr. Le Dantec studied in Paris under Pasteur, Metchnikoff, and other great masters. His doctorate thesis dealt with intra-cellular digestion in the Protozoa. Although he returned at times to similar investigations, e.g. on Sporozoa and Bacteria, he was led by temperament and by circumstances to a kind of life which the pure investigator often fails to understand. On the one hand, Le Danteo was, as he said himself, an intellectual adventurer; he could not desist from the pursuit of the elusive-What is life? What is individuality? What is personality? What is sex? What is evolution? What is knowledge? His last book, which was published this year, is entitled "Savoir." On the other, he had the vocation of a teacher, and fulfilled it with an extraordinary industry and enthusiasm, unsparing of his own vital resources. We refer not so much to his work as lecturer in Lyons and préparateur NO. 2494, VOL. 99] 